\title{
КЬИЖЕВНО И НАУЧНО ВЈЕРУЈУ ИВАНА НЕГРИШОРЦА
}

(Жарко Миленковић, Јана Алексић (прир.). Иван Негрищораи: песничке и културолошке доминанте, зборник радова. Грачаница: Дом културе „Грачаница”, 2020)

Међу „зборницима у част”, ово дело посвећено Ивану Негришорцу припада не тако честим зборницима где се именица част чврсто везује за сам рад аутора коме су посвећени текстови. За издвајање ове речи као једне од кључних у делу (и тумачењу дела) Ивана Негришорца заслужни су аутори зборника Иван Негришорац: песничке и културолошке доминанте, али и околности у којима је овај стваралац понео награду „Златни крст кнеза Лазара”. Као што је истакла Марија Шљукић, ауторка рада о лирским доминантама у песничкој трилогији Ивана Негришорца, у светлу обележавања осам стотина година аутокефалности српске Православне цркве, светосавска обележја Негришорчевих дела још јасније су засветлела.

Аутори радова окупљени у овом зборнику су се на прави начин ухватили у коштац са комплексним (књижевним и научним) делом Ивана Негришорца, те са важном културном мисијом писца - професора - председника Матице српске, усмереном ка неговању и промовисању вредности нашег језика, народа и вере. Рад „Песник, историчар књижевности и председник Матице српске Драган Станић: о цркви, језику и народу" Миодрага Матицког сагледава развојни пут књижевних и научних идеја (или, боље рећи, књижевног и научног вјерују) личности која, судећи по делу, деловању или наградама (међу којима је и „Златни крст кнеза Лазара"), несумњиво представља један од стубова наше културе, књижевности и науке. Више радова овог зборника указало је на присуство „немањићке аксиоме” у укупном стваралаштву Ивана Негришорца која се, између осталог, огледа и у утемељењу националне мисије Матице српске, у преиспитивању прилика и неприлика које су судбоносне српском народу, у лучи стихова и беседа којом аутор осветљава путеве препознавања нашег националног бића. Рад Миодрага Матицког сублимира поетичке моменте књижевног рада Ивана Негришорца, и то двема сложеницама: језикопретрес (језикопротрес) и историопретрес. Језик поезије Ивана Негришорца у зборнику је сагледан у контексту књижевне 
традиције (Доситеја, Соларића и Мркаља), где је нарочито указано на језикотворство у поезији Ивана Негришорца јер овај аутор, како се закључује у раду „Песник, историчар књижевности председник Матице српске Драган Станић”, није само „бирао речи славеносрбског језика вредне да оживе" (120), већ је градио нове сложенице и метафоричне синтагме. Језику као једној од средишњих тема поезије Драгана Станића посвећен је и значајан део рада „Лирска доминанта у песничкој трилогији Ивана Негришорца (Везници, Потајник и Светилник)" ауторке Марије Шљукић. Поједини радови зборника приступају компаративној анализи дела Ивана Негришорца (нпр. у односу на дело Светилник Светлане Велмар Јанковић). Сваки од ових радова дотиче се сагледавања дела Ивана Негришорца у односу према традицији (нарочито у релацији са делима Љубомира Симовића, Миодрага Павловића, Васка Попе, Ивана В. Лалића и Милорада Павића) и у односу према постмодернистичким књижевним струјањима. „Историопретрес” у делу Ивана Негришорца средишњи је проблем рада „Феномен истраге предака у есејистици Ивана Негришорца: реконструкција насилног идентитетског прекодирања" Радоја Фемића. Аутор овог рада је анализирао поједине аспекте односа професора Драгана Станића према питањима која се тичу јединства српског духовног и културног простора, односно према „српском националном питању”. „Приљежан читалац, који по давно формулисаном доситејевском узору, слободно мисли и расуђује, препознаће у Негришорчевом тексту мапу духовне и културне постојаности, коју ишчитавањем ваља развити и потом се ње држати, попут избављујућег путоказа, све док се густа магла идентитеске пометње не разиђе пред бистрином колективног катарзичког преображаја." (109) - закључује Фемић указујући на вишеструки значај монографије Истрага предака Драгана Станића. Овај аспект стваралаштва Ивана Негришорца наглашен је и закључком Наде Милошевић Ђорђевић након опсежне анализе збирке Потајник: „Показао је Станић, ненаметљивом поетском топлином, да Србија јесте «велика тајна〉, историјски вишедимензионална, и духовно слојевита. Дозволио јој је да благородном речју, открије своју душу." (91)

Радови о поезији Ивана Негришорца осветљавају најважније аспекте овог корпуса: жанровску интерференцију песничког опуса овог аутора са облицима црквеног песништва и средњовековне књижевности, при чему се закључује да „Негришорац у своје дело уводи, оживљава, лирским есејством преиспитује, десетине жанрова који су кроз векове доживели многе метаморфозе и који су били делатни не само у средњовековној српској књижевној традицији.” („Песник, историчар књижевности и председник Матице српске Драган Станић”, стр. 119). Предмет радова зборника су и религијски код, фолклорно и предачко наслеђе Не- 
гришорчеве поезије („Лирска доминанта у песничкој трилогији Ивана Негришорца” Марије Шљукић и „Средњовековно обликотворно наслеђе у збирци Светилник Ивана Негришорца” Марије Бјелице), интегративна тематско-мотивска обележја песничког опуса Ивана Негришорца међу којима се нарочито издваја каталог светлосних мотива („Прозорљиво око Ивана Негришорца: О Изложби облака (2017) Ивана Негришорца"), као и језик и еуфоничност његове поезије. Рад „Прозорљиво око Ивана Негришорца: О Изложби облака (2017) Ивана Негришорца” Јелене Марићевић Балаћ, наобимнији у овом зборнику, кроз избор из поезије Ивана Негришорца (који је начинио сам аутор) и метафору њеног наслова, уједно синегдоху за песнички опус поменутог аутора, указује на путању његове поетичке (и научне) мисли. Сублимацију свих песникових тражења ауторка овог рада налази у светлости, која је у поезији Ивана Негришорца заступљена у различитим видовима. Светлости Негришорчеве поезије Марићевић Балаћ исцрпно је представила каталозима.

Ауторка рада о лирским доминантама у песничкој трилогији Ивана Негришорца (Везнищи, Потајник и Светилник), Марија Шљукић, сагледала је семантику и значај фолклорног и религијског кода у поезији овог писца, а у оквиру ове теме највише пажње је посветила значају биља (чемпреса, маслине, босиљка и др.) и животиња не само у погледу песниковог „силаска у дубине хришћанске традиције” (52), већ и у домену семантичког и асоцијативног проширења библијских и средњовековних мотива. Рад „Лирска доминанта у песничкој трилогији Ивана Негришорца" осветљава и важност култа Светог Саве у поезији Ивана Негришорца, при чему се нарочито истиче песниково познавање свих нијанси светосавске традиције и значај светслосне симболике овог култа у његовом књижевном и научном раду. Поменути рад указује и на функционалност игре речима у поезији Ивана Негришорца. Фолклорни код поезије Драгана Станића сагледан је и са аспекта жанра (прецизније кроз (пре) кодирање здравица и др. фолклорних лирских облика у Негришорчевој поезији). Из „Камених чтенија”, аутор рада „Песник, историчар књижевности и председник Матице српске Драган Станић” усмерава се ка проблемима „језикопротреса” и „историопретреса” у делима Ивана Негришорца и закључује да се стихови овог аутора доживљавају као „стећци расути по нашој прошлости који нам осветљавају даљи пут” (122). Тако Негришорчевим преиспитивањима улоге и моћи песништва аутор овог рада додаје и преиспитивање прошлости и њених истина, а овај проблем подједнако је заступљен и у десетинама беседа Драгана Станића, и у књижевном опусу. Са овим радом кореспондира оглед Марије Бјелице који збирку Светилник тумачи са формалног аспекта обнављања (односно рекреирања) средњовековник жанрова акатиста и икоса. 
Рад „Комад-парабола или отворени дијалог са традицијом (Истрага је у току, зар не? Ивана Негришорца)" Кристине Топић представља значајан допринос мање истраженом подручју Негришорчевог књижевног рада и то путем анализе жанровских карактеристика драме истакнуте насловом, функционисања елемената жанра параболе у контексту модерне драме, те путем отварања низа нових питања-рукаваца у сагледавању драмског дела Ивана Негришорца, као што су заједничке особине овог дела опуса поменутог писца, однос традиције и модерног у драми, те поруке ових дела. „Негришорац прави варку и дискутује са традиционалном свешћу, на тај начин што улази у њен систем изнутра" (73), а „избочине” у драми пукотине су кроз које треба преиспитати жанр, функцију хумора, гротеске и ироније, те сумњати у стварност неки су од закључака ауторке поменутог рада који се дотичу поетичких обележја Негришорчеве драме. У овом раду истакнути су сликовитост, живост и особеност драме Истрага је у току, зар не?, те симболичко и реалистичко значење њеног завршетка. „Иронија јесте што овај комад иронија није" (79), закључује Топић и отвара нове, постмодернистичке рукавце у тумачењу ове драме.

Зборник доноси и слово о стваралаштву Ивана Негришорца из пера Матије Бећковића („Три записа о Ивану Негришорцу: Негришорчев подвиг Драгана Станића") и кроз разговор Михајла Пантића са лауреатом награде „Златни крст кнеза Лазара” о поезији као начину живота где се још једном, сада гласом самог аутора, подстакнутим питањима значајног проучаваоца српске књижевности и савременог писца, а у многоме књижевног и научног Негришорчевог/Станићевог савременика, разоткрива књижевно и научно вјерују аутора у чију је част формиран овај садржајан зборник огледа, студија, есеја и књижевних разговора.

Овај достојни наследник зборника о песнику Ивану Негришорцу из 2012. године (Краљево: Повеља) досадашња тумачења дела овог аутора проширио је новим увидима у његов поетски и драмски опус, али и осветљавањем најзначајнијих путева књижевне, културе и друштвене мисије једне од данас стожерних личности поменутих области. Захваљујући аспектима са којих су аутори радова окупљених у овом зборнику приступили свестраном делу добитника награде „Златни крст кнеза Лазара”, односно „укупности” у погледу елемената његовог опуса, изабраних тема и проблема, можемо закључити да је овај зборник један значајан, „укупан” документ о делу и личности Драгана Станића - Ивана Негришорца.

\section{Мирјана Д. Бојанић Ћирковић \\ Универзитет у Нишу Филозофски факултет}

